\title{
Effect of $\alpha$-Lipoic Acid on Proteasomal Induction: Protection against Oxidative Damage in Human Skin Fibroblasts Cell Line NHDF
}

\author{
Sohely Sikdar, Maria Papadopoulou, Jacques Dubois \\ Laboratoire de Chimie Bioanalytique, Toxicologie et Chimie Physique Appliquée, Faculté de Pharmacie, \\ Université Libre de Bruxelles (ULB), Brussels, Belgium \\ Email: Sohely.Sikdar@ulb.ac.be
}

How to cite this paper: Sikdar, S., Papadopoulou, M. and Dubois, J. (2017) Effect of $\alpha$-Lipoic Acid on Proteasomal Induction: Protection against Oxidative Damage in Human Skin Fibroblasts Cell Line NHDF. Pharmacology \& Pharmacy, 8, 292-305. https://doi.org/10.4236/pp.2017.89022

Received: March 17, 2017

Accepted: September 26, 2017

Published: September 29, 2017

Copyright $\odot 2017$ by authors and Scientific Research Publishing Inc. This work is licensed under the Creative Commons Attribution International License (CC BY 4.0).

http://creativecommons.org/licenses/by/4.0/ (c) (i) Open Access

\begin{abstract}
As human skin is daily exposed to oxidative stress causing various unesthetical abnormalities, the road to effective anti-aging substances is being widely investigated. 20S proteasome is a key pathway in the breakdown of oxidized proteins. But its activity declines dramatically in aging cells. Nrf2 inducers $\alpha$-lipoic acid (LA) and sulforaphane (SFN) have been described in the dietary industries for their antioxidant effects on various cell lines. However, since little is yet known about LA's capacity to protect skin cells from premature and extrinsic aging; our aim was to demonstrate the beneficial effect of LA on the cellular detoxification systems. On this purpose, we evaluated its effects against injuries induced by $\mathrm{H}_{2} \mathrm{O}_{2}$ in NHDF and its likely positive effect on the chymotrypsin-like (CT-like) activity of $20 \mathrm{~S}$ proteasome, using SFN as a reference. The cellular content in proteins was measured, as well as the production of Reactive Oxygen Species (ROS). Also, the induction of the proteasomal protein expression was investigated. The results show that after $48 \mathrm{~h}$ treatment, LA significantly decreased the percentage of ROS positive cells. Also, LA decreased the level of $\mathrm{H}_{2} \mathrm{O}_{2}$-induced carbonylated proteins and increased the proteasomal activity. Furthermore, LA upregulated the expression of the $20 \mathrm{~S}$ proteasome $\beta$-subunit responsible for the CT-like activity (PSMB5). Overall, both molecules enhanced cell proliferation over 8 days. So, our investigation found evidence of the higher capacity of LA to induce $20 \mathrm{~S}$ proteasome activity with less toxicity in human fibroblasts compared to reference molecule SFN. These results tend to demonstrate that the induction of the proteasomal activity might be a part of the antioxidant potential of LA. To our knowledge, this is the first study to elucidate the capacity of LA to activate
\end{abstract}


detoxification systems in human cell lines through the induction of 205 proteasome.

\section{Keywords}

Lipoic Acid, Proteasome, Skin Fibroblasts, Oxidative Stress

\section{Introduction}

As human skin is daily exposed to oxidative stress causing various unesthetical abnormalities, the road to effective anti-aging substances is being widely investigated.

The antioxidant role of lipoic acid has been known for decades. Also called "the universal antioxidant", lipoic acid is a disulfide derivative of octanoic acid produced by human body [1]. Currently, it is attracting attention as a nutritional supplement because of its unique antioxidant properties and broad spectra of cellular functions. $\alpha$-lipoic acid exerts its antioxidant effects through its direct radical scavenging properties and its redox interaction with other antioxidants [2] [3]. Although it has been widely studied, little is known about its ability to protect skin cells against external oxidative damage. It has been described that LA has the capacity to scavenge ROS in fibroblasts [4] but there is yet no data insuring that lipoic acid might act as an inducer of natural defense in this cell line, thus protecting them against terminal products of oxidative stress such as carbonylated proteins [5] through proteasome activation in human fibroblasts. Damage to cellular components by reactive oxygen species is believed to be an important factor contributing to the aging process. Likewise, the progressive failure of maintenance and repair is believed to be a major cause of biological aging. Cellular aging is characterized by the accumulation of oxidatively modified proteins, a process that results, at least in part, from impaired protein turnover. Indeed, oxidized protein buildup with age may be due to increased protein damage, decreased elimination of oxidized protein (i.e., repair and degradation), or a combination of both mechanisms [6]. Since the proteasome has been implicated in both general protein turnover and the removal of oxidized protein, the fate of the proteasome during aging has recently received considerable attention. Evidence was brought that an age-related decrease in proteasome activity weakens cellular capacity to remove oxidatively modified proteins and that the loss in proteasome activity during aging rises from at least three mechanisms: decreased proteasome expression; alterations and/or replacement of proteasome subunits and formation of inhibitory cross-linked proteins [7]. The $20 \mathrm{~S}$ proteasome is a cytosolic multicatalytic complex that plays a first class role in the breakdown of dysfunctional and misfolded proteins resulting from the extrinsic oxidative aggression [8] [9]. The proteasome subunits expression is now believed to be dependent of the Keap1-Nrf2 pathway, which plays a major role 
in other antioxidant mechanisms [10] [11] and that is known to be highly activated by LA and SFN [12] [13]. On this premise, we evaluated the effects of LA on the biology on human fibroblasts in vitro and more importantly on its capacity to induce $20 \mathrm{~S}$ proteasome activity. In this study, we evaluated the protective effect of LA against artificially induced injuries in NHDF and compared them to those exhibited by sulforaphane [(-)1-isothiocyanato- $4 R$-(methylsulfinyl)-butane] (SFN). Sulforaphane is one of the most described isothiocyanate for its anticancerous and antioxidant effects on various cell lines through the Nrf2 pathway [14] [15] [16]. As a matter of fact, it has been considered as a good candidate for protection against premature sking aging and its capacity to induce chymotrypsin-like (CT-like) activity of proteasome in murin fibroblasts has been demonstrated [10].

In this study, the cytotoxicity of LA and SFN was first assessed using MTT colorimetric assay. Routine concentrations between 0.1 and $100 \mu \mathrm{M}$ were tested. The $20 \mathrm{~S}$ proteasome activity was studied using chemiluminescent method involving the clivage of SUC-LLV-aminoluciferin. Then, the expression of the $\beta$-subunit 5 (PSMB5) was measured using classic Western-Blot method. The content in carbonylated proteins and the intracellular ROS positive cells level were also measured after treatment with LA and SFN for $48 \mathrm{~h}$ prior to aggression with $10 \mu \mathrm{M} \mathrm{H}_{2} \mathrm{O}_{2}$ for $30 \mathrm{~min}$. Finally, cells were counted after treatment with different concentrations of LA and SFN during 8 days in order to determine their effects on cell proliferation.

\section{Material and Methods}

\subsection{Cell Culture}

Adult NHDF from a 70 year-old donor were obtained from Promocell (Heidelberg, Germany). Cells were used between passages 4 and 12. NHDF cells were grown in DMEM (Dulbecco's modified Eagle's medium) supplemented with 5\% fetal bovine serum, $100 \mathrm{U} / \mathrm{ml}$ of penicillin, and $100 \mathrm{mg} / \mathrm{ml}$ of streptomycin at $37^{\circ} \mathrm{C}$ in $5 \% \mathrm{CO} 2$ in $25-\mathrm{cm}^{2}$ tissue culture flasks. Cell culture medium was regularly changed.

\subsection{MTT Cytotoxicity Assay}

NHDFs viability was determined using a colorimetric MTT (3-[4,5-dimethylthiazol-2yl-diphenyl tetrazolium bromide) assay as detailed previously (Sikdar et al., 2014). For MTT test, NHDF cells were plated in 96 -well plates at a density of $5 \times 10^{4} \mathrm{cells} / \mathrm{ml}$ in DMEM F-12 media and incubated for $24 \mathrm{~h}$ at $37^{\circ} \mathrm{C}$. They were then treated with SFN and LA at concentrations from 0.1 to $100 \mu \mathrm{M}$ and incubated for $72 \mathrm{~h}$ at $37^{\circ} \mathrm{C}$. Cells were then incubated with $0.5 \mathrm{mg} / \mathrm{ml}$ MTT for 4 hours under culture conditions. At the end of the incubation period, the medium was removed and $100 \mu \mathrm{D}$ DMSO (dimethyl sulfoxide) was added. The optical density was read at $570 \mathrm{~nm}$ using a Biorad 650RX microplaque reader. The cells exhibiting blue formazan/endosomes were considered as reactive cells whe- 
reas the ones not displaying formazan/endosomes were labeled as non-reactive cells. Concentration of sample that inhibited $50 \%\left(\mathrm{IC}_{5} \mathrm{O}\right)$ of cell growth was determined over six replicates with graphical regression method on dose-response curves.

\subsection{Determination of 20S Proteasome Activity}

96-well white, clear bottom polystyrene tissue culture plates (Corning, Tewksbury, MA) were seeded with 10,000 cells/ $\mathrm{ml}$ of medium. After $24 \mathrm{~h}$, medium was replaced with medium containing $0.05 \mu \mathrm{M}$ SFN and $1 \mu \mathrm{M}$ LA. Cells were incubated for $48 \mathrm{~h}$ prior to chymotrypsin-like proteasome activity assays using the Proteasome-Glo cell-based luminescent assay (Promega, Madison, WI). Cells were permeabilized with digitonin $0.02 \%$ and then the assay was carried out as described by manufacturer. The proteasome activity was determined by chemiluminescence using on microplate luminometer (Active GLO LR-100). All results were normalized to the values obtained on cells treated with $10 \mu \mathrm{M}$ MG-132, a well-known proteasome inhibitor.

\subsection{Protein Expression Measurements}

Western blot analyses were performed as detailed previously [17]. Briefly, $20 \mu \mathrm{g}$ of denaturated protein extracts was loaded in a polyacrylamide gel. After electrophoresis, proteins were transferred onto a polyvinylidene fluoride membrane. To avoid aspecific binding of the antibodies, membranes were first blocked in a $5 \%$ milk buffer for $1 \mathrm{~h}$. The proteins were then detected by overnight incubation at $4^{\circ} \mathrm{C}$ with anti-PSMB5 antibody (dilution of 1:200; Abcam, Cambridge, UK). Secondary antibodie was purchased from Pierce (Perbio Science, Erembodegem, Belgium) and was incubated for $1 \mathrm{~h}$ at room temperature. Control experiments included the omission of the incubation step with the primary antibodies (negative control). GAPDH immunoblot analysis was then performed on each membrane to assess the integrity and quantity of the extracts. Western blots were developed using the Pierce Supersignal Chemiluminescence system.

\subsection{Determination of Carbonyl Content}

T25 flasks were seeded with 100000 cells/flask. The treatment with SFN and LA was made as described in the proteasomal activity assay. Cells were incubated 48h prior to treatment with $10 \mu \mathrm{M}$ of $\mathrm{H}_{2} \mathrm{O}_{2}$ for 30 min and detection of carbonyl contents using 2,4-dinitrophenylhydrazine (DNPH). The following method was inspired from Dalle-Donne with few modifications [18].

Briefly, cells were washed with phosphate-buffered saline (PBS) were centrifuged twice (5 - $10 \mathrm{~min}$ at $14,000 \mathrm{rpm}$ in a tabletop microcentrifuge) at room temperature to eliminate all particulate matter that might interfere with the reaction. The diluted proteins are precipitated with cold trichloroacetic acid (TCA, 20\% final concentration) and then collected by centrifugation for $5 \mathrm{~min}$. A solution of $10 \mathrm{mM} \mathrm{DNPH}$ in $2 \mathrm{~N} \mathrm{HCl}$ is added to the protein pellet of each 
sample, with $2 \mathrm{~N} \mathrm{HCl}$ only added to corresponding sample aliquot reagent blanks. Samples are allowed to stand in the dark at room temperature for $1 \mathrm{~h}$ with vortexing every $15 \mathrm{~min}$; they are then precipitated with 10\% TCA (final concentration) and centrifuged for $5 \mathrm{~min}$ at $10,000 \mathrm{rpm}$ at $4^{\circ} \mathrm{C}$. The supernatants are discarded; the protein pellets are washed once more with $10 \% \mathrm{TCA}$, and then washed three times with $1 \mathrm{ml}$ portions of ethanol/ethylacetate $(1: 1, \mathrm{v} / \mathrm{v})$ to remove any free DNPH. Samples are then resuspended in $6 \mathrm{M}$ guanidine hydrochloride at $37^{\circ} \mathrm{C}$ for 15 min with vortex mixing.

Plate was read in a microplate reader at $365-380 \mathrm{~nm}$.

\subsection{Determination of Cell Proliferation}

6-wells plates were seeded with 5000 cells/ml of medium. After $24 \mathrm{~h}$, they were treated with $0-5 \mu \mathrm{M}$ LA and SFN for 8 days and supplemented with $1 \%$ FBS every 3 days.

Cells were then washed with PBS and counted with Trypan Blue solution $(1: 1)$.

\section{7. $\mathrm{H}_{2} \mathrm{O}_{2}$-Induced ROS Production}

24-wells plates were seeded with 10,000 cells/ml of DMEM 10\% FBS. After $24 \mathrm{~h}$, they were pre-treated with $0.025-1 \mu \mathrm{M}$ SFN and LA.

After $48 \mathrm{~h}$ treatment, the $\mathrm{H}_{2} \mathrm{O}_{2}$ group was treated with $10 \mu \mathrm{M} \mathrm{H}_{2} \mathrm{O}_{2}$ for $30 \mathrm{~min}$. The control group was treated with PBS. Then, cells were washed twice with PBS, centrifugated a $2000 \mathrm{rpm}$ for 5 min and then incubated with $600 \mathrm{nM}$ of dichlorofluorescin diacetate (DCFDA).

ROS formation was determined by flow cytometry.

\subsection{Statistical Analyses}

Statistical comparisons between groups were established by carrying out the nonparametric Mann-Whitney test. The statistical analyses were performed using Statistica software (Statsoft, Tulsa, USA).

\section{Results}

\subsection{MTT Cytotoxic Assay}

The $\mathrm{IC}_{50}$ in vitro cytotoxic concentrations SFN and LA were determined with a MTT colorimetric assay on NHDF cell line after three days of culturing the cells (Figure 1). Results showed that LA presents no cytotoxic effect at the studied concentrations, while SFN exherts cytotoxicity at $5 \mu \mathrm{M}$. These results will be useful for the concentrations range choice in further experiments.

\subsection{Proteasomal Activity and PSMB5 Subunit Expression}

Figure 2 shows that the luminescence intensity of LA-treated group is significantly higher than the control group suggesting an induction of the chymotrypsin- 


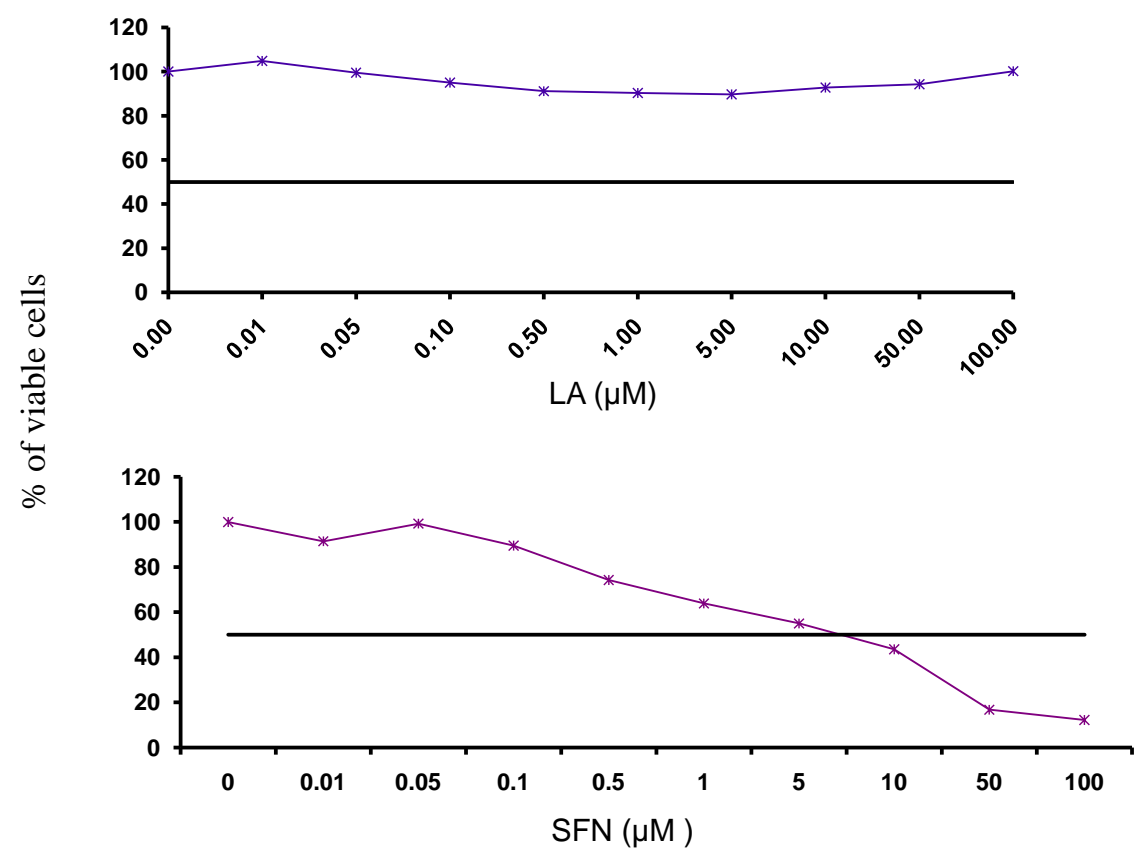

Figure 1. Cytoactivity of NHDF cells at different LA and SFN concentrations; the incubation time was $72 \mathrm{~h}$.

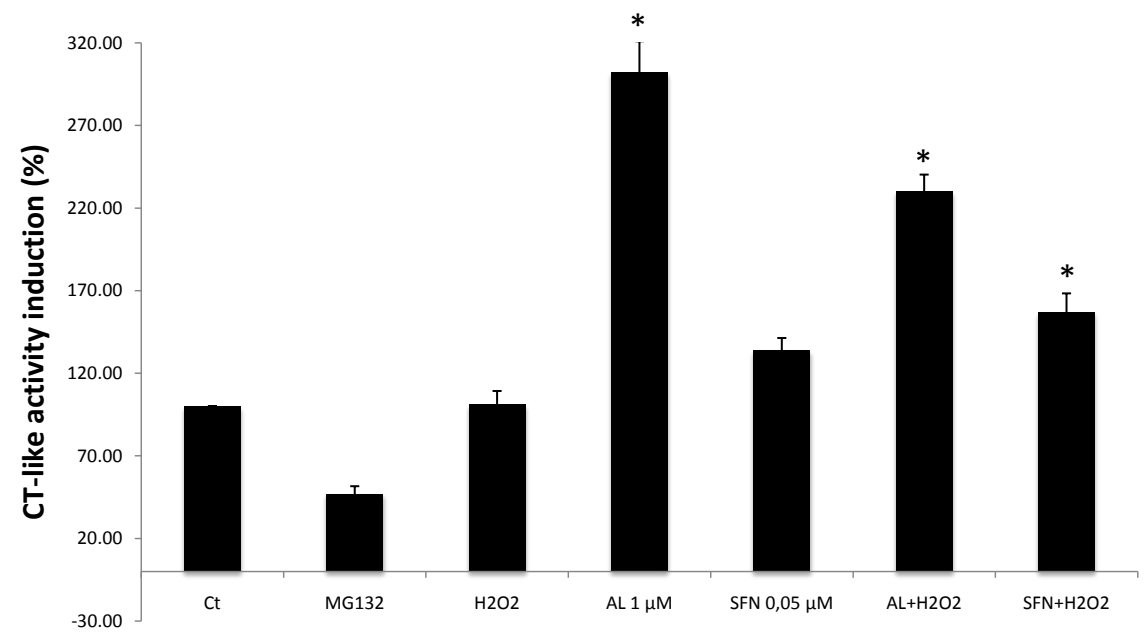

Figure 2. Effects of LA and SFN at respectively $1 \mu \mathrm{M}$ and $0,05 \mu \mathrm{M}$ on the CT-like activity of 20 S proteasome. ${ }^{*}: \mathrm{p}<0.05$. Each value represents the mean $\pm \operatorname{SEM}(\mathrm{n}=4)$.

like activity of the $20 \mathrm{~S}$ proteasome. SFN seems not to induce significantly the chymotrypsin-like activity in NHDF cell line. This result is supported by the Western-Blotting showed on Figure 3 where we can see that $1 \mu \mathrm{M}$ LA upregulates expression of PSMB5 protein whereas SFN doesn't.

\subsection{Carbonyl Content}

Figure 3 shows the effect of LA and SFN on the level of intracellular carbonylated proteins induced by $10 \mu \mathrm{MH}_{2} \mathrm{O}_{2}$. We can see that $\mathrm{H}_{2} \mathrm{O}_{2}$ highly increases the intracellular carbonyl content from $100 \%$ (control) to $1200 \%$. LA and SFN 


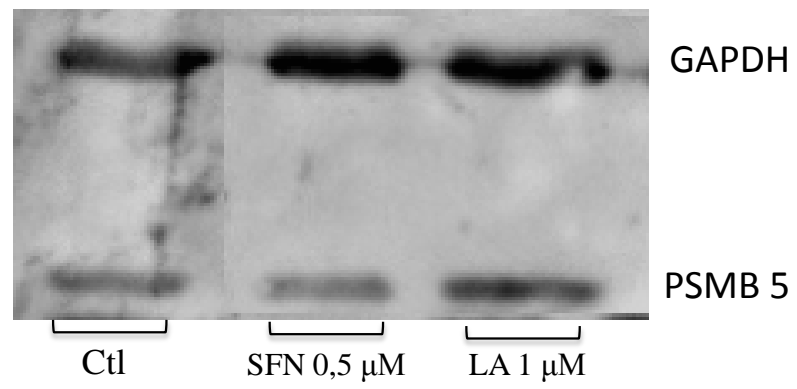

Figure 3. Regulation of PSMB5 expression in NHDF with LA and SFN. GADPH was used as whole protein level control.

significantly reduce the carbonylation capacity of $\mathrm{H}_{2} \mathrm{O}_{2}$ at low concentrations: down to $300 \%$ with $0.05 \mu \mathrm{M}$ of SFN, and down to control level with $0.5 \mu \mathrm{M}$ of LA.

\subsection{Cell Proliferation}

In the recent past, SFN has been studied for its anticancer and antitumor properties in-vitro as in-vivo [19] [20]. It is a well-known hormetic substance as it shows cytotoxic effects at high concentrations and antioxidant effects at lower concentrations. Our results tend to confirm this statement as shown on Figure 4. At $1 \mu \mathrm{M}$, LA enhances cell proliferation up to $177 \%$ from the control level after 8 days incubation. SFN shows better effect at $0.05 \mu \mathrm{M}$ with a proliferation pic upto $235 \%$. At higher concentrations, both present high cytotoxicity after 8 days treatment.

\subsection{ROS Production}

As shown in Figure 5, the fluorescence intensity of the $\mathrm{H}_{2} \mathrm{O}_{2}$-treated group was significantly higher than the control group, which showed that $\mathrm{H}_{2} \mathrm{O}_{2}$ treatment led to cell injury and a large amount of ROS generated in the NHDF cells. LA and SFN pre-treatment have a tendency to reduce the ROS concentration respectively at $0.5 \mu \mathrm{M}$ and $0.1 \mu \mathrm{M}$ and LA.

\section{Discussion}

$20 \mathrm{~S}$ proteasome has been described as a key element of the dysfunctional proteins degradation [9]. With aging and exposure to environmental stressors, there are two putative mechanisms that lead skin cells to decline; the accumulation of oxidized proteins [21] and the impairment of the proteasome system and its less effective capacity to eliminate these proteins [7] [22].

NHDF cell line was believed to be a good model for the study of oxidative damage on the skin as they are a non-transformed and non-tumorigenic human cell type. They could more easily be compared with human and facilitate extrapolation of in vitro data to human without going through animal models.

Toxicity of LA on NHDF cell line has not been discussed previously but our results showed the promising lack of cytotoxicity (Figure 1) that raises the 


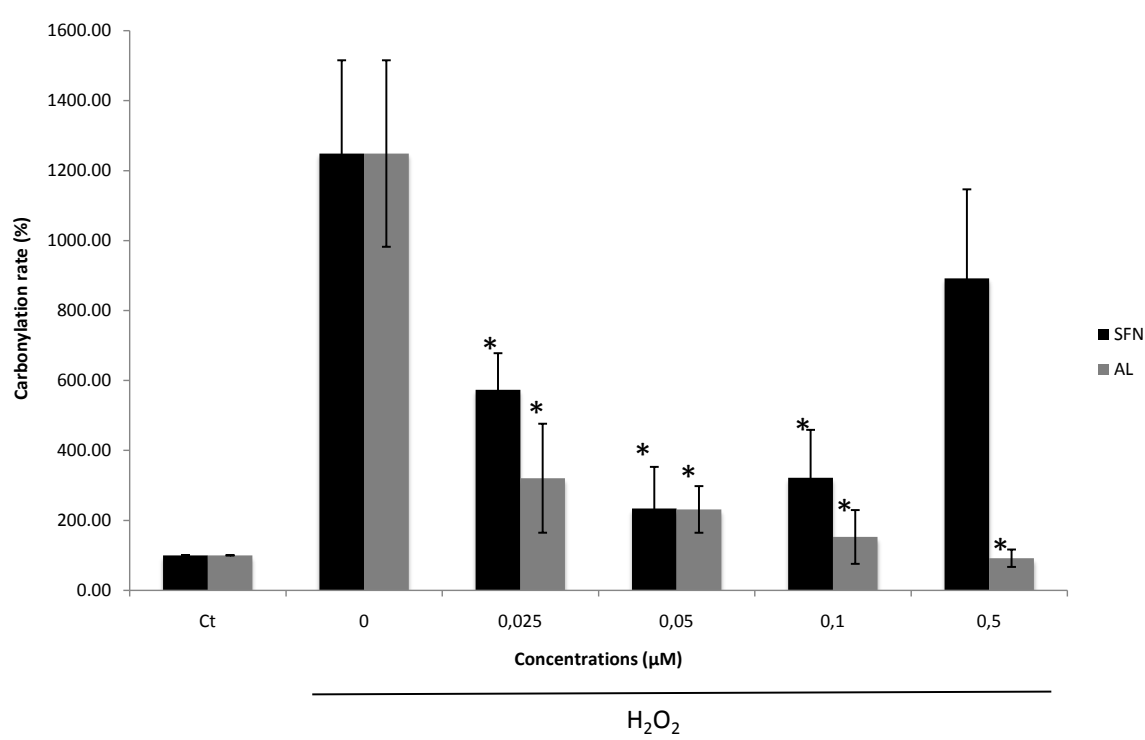

Figure 4. Effects of LA and SFN on the level of protein carbonyls induced by $10 \mu \mathrm{M}$ of $\mathrm{H}_{2} \mathrm{O}_{2} .{ }^{*}: \mathrm{p}<0.05 /$ Each value represents the mean \pm SEM $(\mathrm{n}=3)$.

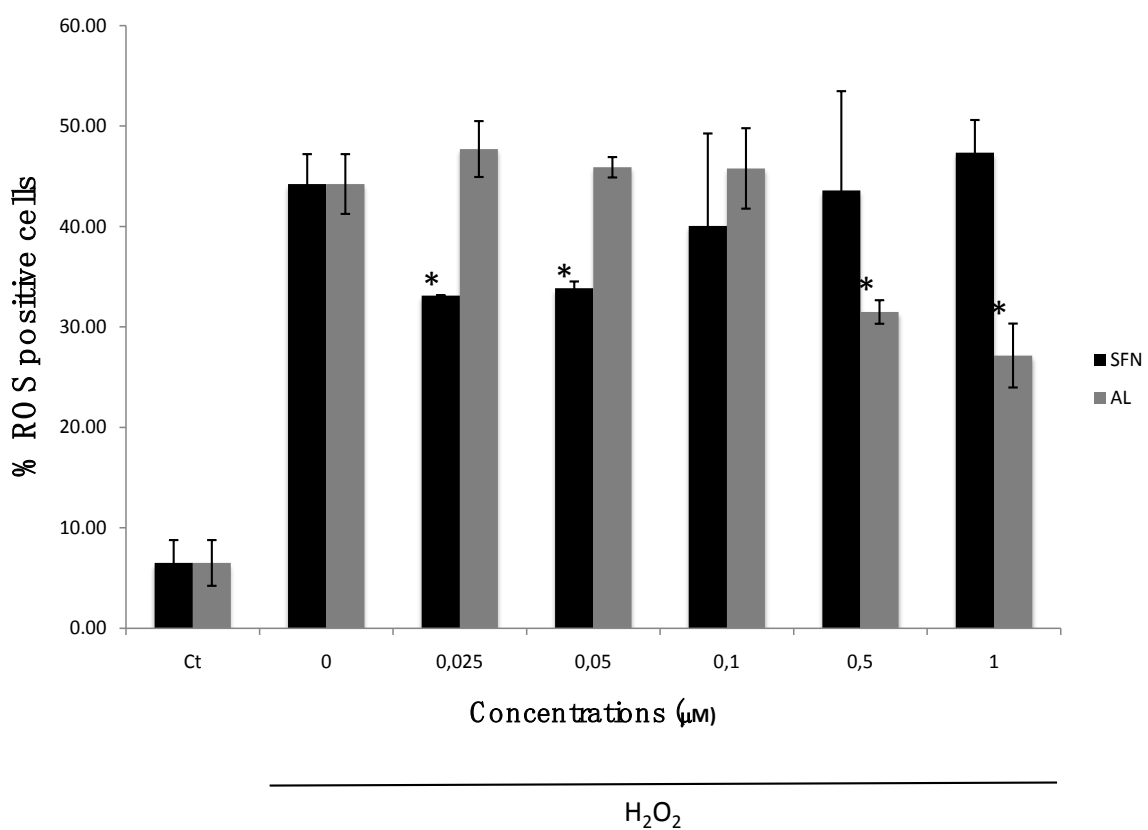

Figure 5. Effects of LA and SFN on intracellular ROS production. ${ }^{\star}: \mathrm{p}<0.05$. Each value represents the mean $\pm \operatorname{SEM}(n=4)$.

interest of using it as an anti-aging ingredient.

Studies showed that the proteasome activity of healthy centenarians was comparable to the younger rather than the older control donors derived cultures, suggesting that proteasome is a major actor in a successful aging process [6]. As most of the works on proteasome tend to find inhibitors for the anti-cancer strategy, there are very few proteasome activators that have been studied nowadays and some of them have been identified to activate $26 \mathrm{~S}$ proteasome in dege- 
nerative diseases [23]. Oleuropeine showed positive effect on 20S proteasome activity and on senescence of embryonic human fibroblasts. Although the activation rate was only of 1.2 fold, it was the first study to suggest that protea some activators might have the potential to be developed into anti-aging agents [24]. Our work attempts to enhance this theory. LA surely showed a high activation rate on $20 \mathrm{~S}$ proteasome (Figure 2) but its effects on cellular senescence have not been studied. The descrease in carbonylated protein content (Figure 4) and the increased cell proliferation (Figure 5) indicate though that LA might contribute to protect cells from early extrinsic ageing. Also, in contrast of oleuropeine that is thought to activate protesome through structural changes in the catalytic area, there are some evidence suggesting that LA acts at another level. In fact, we showed the mild upregulation of PSMB5 with LA which is known to activate Nrf2 pathway. In 2003, Kwak et al. showed that antioxidants induced the overexpression of $20 \mathrm{~S}$ proteasome $\beta$-subunit through the activation of Nrf2-Keap1 signalisation [25].

$\mathrm{H}_{2} \mathrm{O}_{2}$ has been used to generate ROS and induce the formation of carbonylated proteins as it is well accepted and widely used suggest in overall studies on oxidative stress. Each type of cell line shows a different sensibility to $\mathrm{H}_{2} \mathrm{O}_{2}$. In order to adjust the concentration of $\mathrm{H}_{2} \mathrm{O}_{2}$ needed in our study, NHDF cell line was treated with different concentrations. Cell viability after treatment with 10 $\mu \mathrm{M} \mathrm{H}_{2} \mathrm{O}_{2}$ for 30 min showed a significant difference in ROS production compared with the control group. Although the level of intracellular ROS in NHDF cells treated with a higher $\mathrm{H}_{2} \mathrm{O}_{2}$ concentration $(10 \mathrm{mM})$ was more substantial, the floating dead cells were useless in our study where the recovery of weakened cells was expected.

The in vitro ROS scavenging capacities of LA has been described in previous studies that have been made without any cellular models [4]. In 2009, Davis and al. showed the radioprotective effect of LA that decreased raditation-induced intracellular ROS in murine fibroblasts at $100 \mu \mathrm{M}$ as well as its capacity to restore other cellular antioxidants (catalase, gluthatione reductase) [26]. But Lyublinskaya and al. recently demonstrated LA's pro-oxidant effect on murine fibroblasts between 0.1 and $1.25 \mu \mathrm{M}$ [27].

Our results meet both findings halfway as we demonstrated anti-ROS effect at low concentrations. We believe that LA acts as a ROS scavenging agent in NHDF cell line but the hypothesis has not been confirmed.

Previously, LA has been described as an antioxidant acting at two different levels; through scavenging free radicals directly in the media, or, through its recycling process in dihydrolipoic acid and the regeneration of ascorbate and vita$\min \mathrm{E}$ [2] [3]. Here, we elucidated a third mechanism for the antioxidant capacity of LA in skin cells, which is the stimulation of inner detoxification mechanisms in order to eliminate unwanted oxidative products. Although it has been previously described in IPEC-J2 cell lines [1] that LA shows pre-protective effects towards oxidative stress, our study brings a whole new approach of the 
prophylactic potential of LA against human skin aging through the induction of the $20 \mathrm{~S}$ proteasome leading to the decrease of oxidative damage.

Although several studies shows the anti-proliferative capacity of LA on tumor cells [28] [29] [30], on the other hand, one recent study have reported the beneficial effect of LA promoting cell survival, angiogenesis and neuroregeneration after brain injury [31]. In our study, LA increased the number of cells after 8 days in culture suggesting the applicability of using LA in cell culture to quicken proliferation (Figure 6). As fibroblasts are considered the main collagen fabric in the skin, this finding opens the path to collagen production in greater scales and skin restructuration [32]. Thus, LA that has not yet been described previous in studies as a proteasome activator in human skin cells, showed way better induction effect than reference molecule SFN. LA that was known to be a powerful antioxidant through scavenging free radicals, now shows capacity to stimulate natural cellular defense process by activating proteasome and reducing intracellular oxidation products. But, the mechanisms involved in these above-described protection capacities are yet unknown. Therefore, to verify that a portion of the protective effects of LA could occur through induction of $20 \mathrm{~S}$ proteasome, the previous experiments are being repeated with the use of MG-132 in each condition (preliminary data not shown). Also, to demonstrate the implication of the activation of Nrf2 in the induction of $20 \mathrm{~S}$ proteasome by LA, further studies will be done using Nrf2 siRNA. Although Nrf2 and proteasome might not be exclusive pathways in the protection process of LA, they can provide an additional backing in the oxidative stress adaptation.

\section{Conclusion}

In conclusion, $10 \mu \mathrm{M}$ of $\mathrm{H}_{2} \mathrm{O}_{2}$ put in contact with the cells for 30 min can

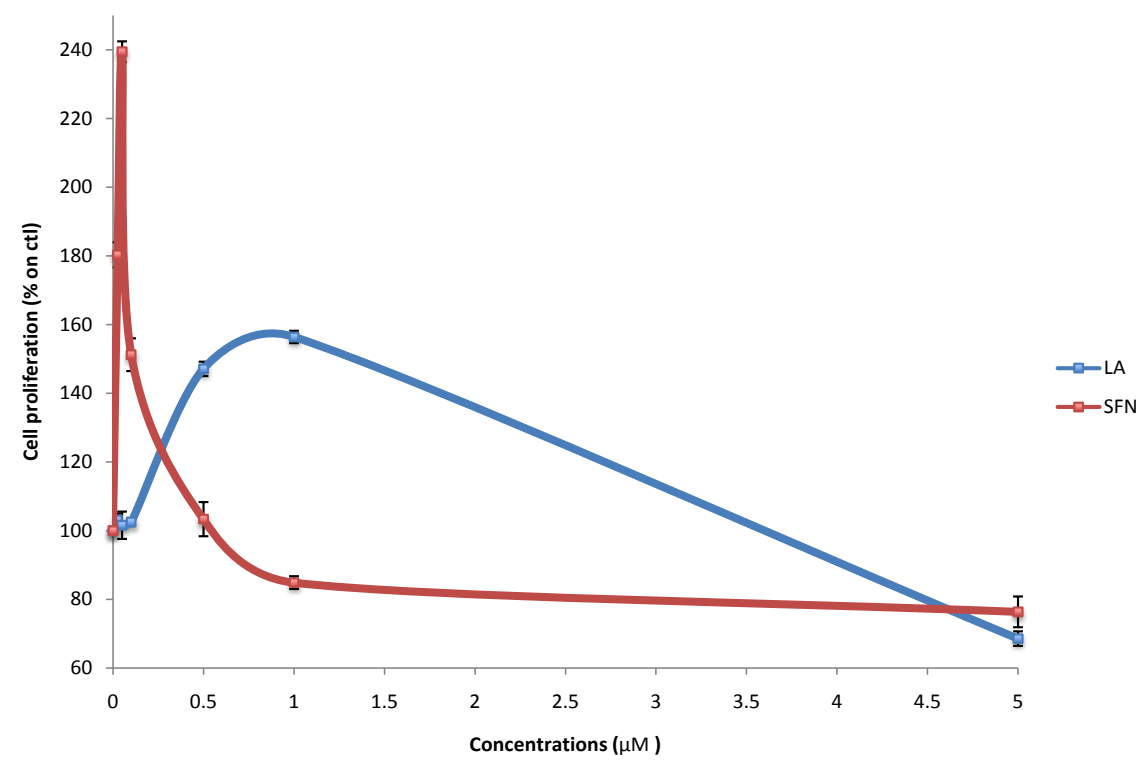

Figure 6. Proliferation rate of NHDF cells with different concentrations of LA and SFN. Each value represents the mean $\pm \operatorname{SEM}(n=4)$. 
significantly reduce the NHDF cell vitality and increases the intracellular free radicals by $45 \%$ while $\mathrm{H}_{2} \mathrm{O}_{2}$ increases the cellular carbonyl content by $10.0 .5-1$ $\mu \mathrm{M}$ of LA for $48 \mathrm{~h}$ protected NHDF from the production of intracellular ROS and carbonylated proteins, reducing them by more than a half and enhanced cell proliferation, possibly through the induction of $20 \mathrm{~S}$ proteasome as LA induced CT-like activity up to near $300 \%$ in human fibroblasts. In the same way, SFN stimulated cell vitality at only $0.05-0.1 \mu \mathrm{M}$ but had less impact on $20 \mathrm{~S}$ protea some activity with only $20 \%$ induction. The assessment on the expression of PSMB showed that LA upregulated the protein, suggesting that the induction of $20 \mathrm{~S}$ proteasome by LA is only partly ascribed to the expression of PSMB5. At this level, it is important to point that, according to MTT test, LA doesn't show any cytotoxicity and can be used in the future at higher concentrations. SFN was confirmed to be cytotoxic on normal human cells and limited in term of concentrations value.

\section{Acknowledgements}

This work was supported by Auriga International s.a. and La Région Wallonne.

\section{References}

[1] Shen, H.H., Lam, K.K., Cheng, P.Y., Kung, C.W., Chen, S.Y., Lin, P.C., Chung, M.T. and Lee, Y.M. (2014) Alpha-Lipoic Acid Prevents Endotoxic Shock and Multiple Organ Dysfunction Syndrome Induced by Endotoxemia in Rats. Shock, 43, 405-411. https://doi.org/10.1097/SHK.0000000000000295

[2] Rahman, K. (2007) Studies on Free Radicals, Antioxidants, and Co-Factors. Clinical Interventions in Aging, No. 2, 219-236.

[3] Rochette, L. and Vergely, C. (2014) Alpha-Lipoic Acid-An Antioxidant with Protective Actions on Cardiovascular Diseases. Systems Biology of Free Radicals and Antioxidants. Springer, Berlin, 1523-1536. https://doi.org/10.1007/978-3-642-30018-9 77

[4] Li, Y., Zhao, Y., Yu, W. and Jiang, S. (2004) Scavenging Ability on ROS of Alpha-Lipoic Acid (ALA). Bioorganic \& Medicinal Chemistry Letters, No. 13, 1115-1118. https://doi.org/10.1016/S0308-8146(03)00279-6

[5] Tsuji-Naito, K., Ishikura, S., Akagawa, M. and Saeki, H. (2010) $\alpha$-Lipoic Acid Induces Collagen Biosynthesis Involving Prolyl Hydroxylase Expression via Activation of TGF- $\beta$-Smad Signaling in Human Dermal Fibroblasts. Connective Tissue Research, 51, 378-387. https://doi.org/10.3109/03008200903486188

[6] Chondrogianni, N., Petropoulos, I., Franceschi, C., Friguet, B. And Gonos, E.S. (2000) Fibroblast Cultures from Healthy Centenarians Have an Active Proteasome. Experimental Gerontology, No. 35, 721-728. https://doi.org/10.1016/S0531-5565(00)00137-6

[7] Carrard, G., Bulteau, A.L., Petropoulos, I. and Friguet, B. (2002), Impairment of Proteasome Structure and Function in Aging. International Journal of Biochemistry \& Cell Biology, 34, 1461-1474. https://doi.org/10.1016/S1357-2725(02)00085-7

[8] Coux, O., Tanaka, K. and Goldberg, A.L. (1996) Structure and Functions of the 20S and 26S Proteasomes. Annual Review of Biochemistry, 65, 801-847. https://doi.org/10.1146/annurev.bi.65.070196.004101 
[9] Davies, K.J. (2001) Degradation of Oxidized Proteins by the 20S Proteasome. Biochimie, 83, 301-310. https://doi.org/10.1016/S0300-9084(01)01250-0

[10] Pickering, A., Linder, R., Zhang, H., Forman, H. and Davies, K. (2012) Nrf2-Dependent Induction of Proteasome and Pa28 Regulator Are Required for Adaptation to Oxidative Stress. Journal of Biological Chemistry, No. 287, 10021-10031. https://doi.org/10.1074/jbc.M111.277145

[11] Chapple, S.J., Siow, R.C. and Mann, G.E. (2012) Crosstalk between Nrf2 and the Proteasome: Therapeutic Potential of Nrf2 Inducers in Vascular Disease and Aging. The International Journal of Biochemistry \& Cell Biology, 44, 1315-1320.

[12] Shinkai, Y., Sumi, D., Fukami, I., Ishii, T. and Kumagai, Y. (2006) Sulforaphane, an Activator of Nrf2, Suppresses Cellular Accumulation of Arsenic and Its Cytotoxicity in Primary Mouse Hepatocytes. FEBS Letters, 580, 1771-1774.

[13] Lin, Y.C., Lai, Y.S. and Chou, T.C. (2013) The Protective Effect of Alpha-Lipoic Acid in Lipopolysaccharide-Induced Acute Lung Injury Is Mediated by Hemeoxygenase-1. Evidence-Based Complementary and Alternative Medicine, 2013.

[14] Chinembiri, T.N., du Plessis, L.H., Gerber, M., Hamman, J.H. and du Plessis, J. (2014) Review of Natural Compounds for Potential Skin Cancer Treatment. Molecules, 19, 11679-11721. https://doi.org/10.3390/molecules190811679

[15] Boddupalli, S., Mein, J.R., Lakkanna, S. and James, D.R. (2012) Induction of Phase 2 Antioxidant Enzymes by Broccoli Sulforaphane: Perspectives in Maintaining the Antioxidant Activity of Vitamins A, C, and E. Frontiers in Genetics, 7, 1-15.

[16] Benedict, A., Knatko, E. and Dinkova-Kostova, A.T. (2012) The Indirect Antioxidant Sulforaphane Protects against Thiopurine-Mediated Photooxidative Stress. Carcinogenesis, 1-10.

[17] Mégalizzi, V., Mathieu, V., Mijatovic, T., Gailly, P., Debeir, O., De Neve, N., Van Damme, M., Bontempi, G., Haibe-Kains, B. and Decaestecker, C. (2007) 4-IBP, a Sigma1 Receptor Agonist, Decreases the Migration of Human Cancer Cells, Including Glioblastoma Cells, in Vitro and Sensitizes Them in Vitro and in Vivo to Cytotoxic Insults of Proapoptotic and Proautophagic Drugs. Neoplasia, 9, 358-369. https://doi.org/10.1593/neo.07130

[18] Dalle-Donne, I., Rossi, R., Giustarini, D., Milzani, A. and Colombo, R. (2003) Protein Carbonyl Groups as Biomarkers of Oxidative Stress. Clinica Chimica Acta, 329, 23-38.

[19] Zanichelli, F., Capasso, S., Cipollaro, M., Pagnotta, E., Cartenì, M., Casale, F., Iori, R. and Galderisi, U. (2012) Dose-Dependent Effects of R-Sulforaphane Isothiocyanate on the Biology of Human Mesenchymal Stem Cells, at Dietary Amounts, It Promotes Cell Proliferation and Reduces Senescence and Apoptosis, While at Anti-Cancer Drug Doses, It Has a Cytotoxic Effect. Age, 34, 281-293.

https://doi.org/10.1007/s11357-011-9231-7

[20] Zanichelli, F., Capasso, S., Di Bernardo, G., Cipollaro, M., Pagnotta, E., Cartenì, M., Casale, F., Iori, R., Giordano, A. and Galderisi, U. (2012b) Low Concentrations of Isothiocyanates Protect Mesenchymal Stem Cells from Oxidative Injuries, While High Concentrations Exacerbate DNA Damage. Apoptosis, 17, 964-974. https://doi.org/10.1007/s10495-012-0740-3

[21] Hipkiss, A.R. (2005) Accumulation of Altered Proteins and Ageing: Causes and Effects. Experimental Gerontology, 41, 464-473.

[22] Bulteau, A.L., Szweda, L.I. and Friguet, B. (2002) Age-Dependent Declines in Proteasome Activity in the Heart. Archives of Biochemistry and Biophysics, 397, 298-304. https://doi.org/10.1006/abbi.2001.2663 
[23] Kwak, M.K. (2007) Role of Increased Expression of the Proteasome in the Protective Effects of Sulforaphane against Hydrogen Peroxide-Mediated Cytotoxicity in $\mathrm{Mu}$ rine Neuroblastoma Cells. Free Radical Biology \& Medicine, 43, 809-817.

[24] Katsiki, M., Chondrogianni, N., Chinou, I., Rivett, A.J. and Gonos, E.S. (2007) The Olive Constituent Oleuropein Exhibits Proteasome Stimulatory Properties in Vitro and Confers Life Span Extension of Human Embryonic Fibroblasts. Rejuvenation Research, 10, 157-172. https://doi.org/10.1089/rej.2006.0513

[25] Kwak, M.K. (2003) Antioxidants Enhance Mammalian Proteasome Expression through the Keap1-Nrf2 Signaling Pathway. Molecular and Cellular Biology, 23, 8766-8794. https://doi.org/10.1128/MCB.23.23.8786-8794.2003

[26] Davis, G.D., Masilamoni, J.G., Arul, V., Kumar, M.S., Baraneedharan, U., Paul, S.F., Sakthivelu, I.V., Jesudason, E.P. and Jayakumar, R. (2009) Radioprotective Effect of DL-Alpha-Lipoic Acid on Mice Skin Fibroblasts. Cell Biology and Toxicology, 25, 331-340. https://doi.org/10.1007/s10565-008-9087-5

[27] Lyublinskaya, O.G., Kirpichnikova, K.M. and Gamaley, I.A. (2014) Antioxidant Action on the Level of Reactive Oxygen Species in Normal and Transformed Fibroblasts. Cell and Tissue Biology, 8, 33-37. https://doi.org/10.1134/S1990519X14010088

[28] Feuerecker, B., Pirsig, S., Seidl, C., Aichler, M., Feuchtinger, A., Bruchelt, G. and Senekowitsch-Schmidtke, R. (2012) Lipoic Acid Inhibits Cell Proliferation of Tumor Cells in Vitro and in Vivo. Cancer Biology \& Therapy, 13, 1425-1435. https://doi.org/10.4161/cbt.22003

[29] Michikoshi, H., Nakamura, T., Sakai, K., Suzuki, Y., Adachi, E., Matsugo, S. and Matsumoto, K. (2013) $\alpha$-Lipoic Acid-Induced Inhibition of Proliferation and Met Phosphorylation in Human Non-Small Cell Lung Cancer Cells. Cancer Letters, 335, 472-478.

[30] Artwohl, M., Muth, K., Kosulin, K., de Martin, R., Hölzenbein, T., Rainer, G., Freudenthaler, A., Huttary, N., Schmetterer, L., Waldhäusl, W.K. and BaumgartnerParzer, S.M. (2007) R-(+)-Alpha-Lipoic Acid Inhibits Endothelial Cell Apoptosis and Proliferation: Involvement of Akt and Retinoblastoma Protein/E2F-1. American Journal of Physiology-Endocrinology and Metabolism, 293, E681-E689. https://doi.org/10.1152/ajpendo.00584.2006

[31] Paradells, S., Zipancic, I., Martínez-Losa, M.M., García Esparza, M.A., Bosch-Morell, F., Alvarez-Dolado, M. and Soria, J.M. (2014) Lipoic Acid and Bone Marrow Derived Cells Therapy Induce Angiogenesis and Cell Proliferation after Focal Brain Injury. Brain Injury, 10, 1-16.

[32] Ross, R. (1968) The Fibroblast and Wound Repair. Biological Reviews of the Cambridge Philosophical Society, 43, 51-96.

https://doi.org/10.1111/j.1469-185X.1968.tb01109.x 


\section{Abbreviations}

Nrf2: NF-E2-related factor-2

NHDF: Normal human dermal fibroblast

DMEM: Dubelcco's modified Eagle medium

SFN: sulforaphane

LA: lipoic acid

DMSO: dimethyl sulfoxyde

GAPDH: glyceraldehyde-3-phosphate deshydrogenase

DNPH: dinitrophenyl hydrazine

TCA: Trichloroacetic acid

FBS: fetal bovine serum

PBS: phosphate buffer saline

ROS: reactive oxygen species

DCFDA: 2',7'-dichlorodihydrofluorescein diacetate

siRNA: small interfering RNA

Submit or recommend next manuscript to SCIRP and we will provide best service for you:

Accepting pre-submission inquiries through Email, Facebook, LinkedIn, Twitter, etc. A wide selection of journals (inclusive of 9 subjects, more than 200 journals) Providing 24-hour high-quality service User-friendly online submission system Fair and swift peer-review system Efficient typesetting and proofreading procedure

Display of the result of downloads and visits, as well as the number of cited articles Maximum dissemination of your research work

Submit your manuscript at: http://papersubmission.scirp.org/

Or contact pp@scirp.org 